\title{
Strategi Penguatan Modal Sosial Perempuan Tani dalam Pemanfaatan Lahan Pekarangan Terbatas di Kabupaten Bogor
}

\section{Strategy for Strengthening the Social Capital of the Women Farmers in Home Garden Utilization, Bogor District}

\author{
Ageng Hasanah Sulaiman ${ }^{1}$, Ekawati Sri Wahyuni ${ }^{2}$, dan Soeryo Adiwibowo ${ }^{2}$ \\ ${ }^{1}$ Badan Penyuluhan dan Pengembangan SDM Pertanian, Kementerian Pertanian \\ ${ }^{2}$ Departemen Sains Komunikasi dan Pengembangan Masyarakat, Fakultas Ekologi Manusia, Institut \\ Pertanian Bogor
}

\begin{abstract}
Home garden and people's living area has a potential to be a source of family food. This paper aimed to describe and analyze the performance of the Kawasan Rumah Pangan Lestari (KRPL) Program. Based on the results, a strategy to strengthen the social capital of the women farmers in home garden utilization in Bogor District was formulated. The survey method used to get an overview of the performance of the KRPL in the three KRPL groups. Case studies were used to explore social capital, the role of companion, and administration management in one KRPL group. KRPL's performance showed that, nurseries and demonstration plots (demplot) were not managed properly, Rumah Pangan Lestari (RPL) were still managed independently by members, and administrative management is not yet orderly. Social capital, the role of companion, and administration management also determine the performance of the KRPL. An action program to avoid future KRPL failures has been prepared.
\end{abstract}

Keywords: Home Garden, Social Capital, Women Farmers, Performance, KRPL

\begin{abstract}
Abstrak
Pekarangan dan lahan sekitar tempat tinggal berpotensi sebagai sumber pangan keluarga. Tulisan ini bertujuan untuk mendeskripsikan dan menganalisis kinerja program Kawasan Rumah Pangan Lestari (KRPL) di Kabupaten Bogor. Berdasarkan hasil tersebut dirumuskan strategi penguatan modal sosial perempuan tani pada pemanfaatan lahan pekarangan terbatas di Kabupaten Bogor. Metode survey digunakan untuk mendapatkan gambaran kinerja KRPL di tiga kelompok KRPL. Studi kasus digunakan untuk menggali modal sosial, peran pendamping, dan pengelolaan administrasi pada satu kelompok KRPL. Kinerja KRPL menunjukkan bahwa, kebun bibit dan demplot sudah tidak terkelola dengan baik, Rumah Pangan Lestari (RPL) masih dikelola secara mandiri oleh anggota, dan pengelolaan administrasi kelompok belum tertib. Modal sosial, peran pendamping, dan pengelolaan administrasi turut menentukan kinerja KRPL. Suatu program aksi untuk menghindari kegagalan KRPL di masa mendatang telah disusun.
\end{abstract}

Kata kunci: Pekarangan, Modal Sosial, Perempuan Tani, Kinerja, KRPL

\footnotetext{
${ }^{1}$ Korespondensi penulis

E-mail: agenghasanah@gmail.com
} 


\section{Pendahuluan}

Pembangunan ketahanan pangan dihadapkan pada permasalahan pokok yaitu pertumbuhan permintaan pangan lebih cepat dari pertumbuhan produksinya (Saptana et al 2013). Undang-Undang Nomor 18 tahun 2012 tentang Pangan menyebutkan bahwa pemenuhan konsumsi pangan harus mengutamakan produksi dalam negeri dengan memanfaatkan sumberdaya yang dimiliki. Salah satu kebijakan pemerintah dalam hal ketahanan pangan adalah Gerakan Percepatan Penganekaragaman Konsumsi Pangan (P2KP) Berbasis Sumberdaya Lokal, dimana salah satu implementasinya melalui kegiatan Optimalisasi Pemanfaatan Lahan Pekarangan melalui konsep Kawasan Rumah Pangan Lestari (KRPL).

KRPL adalah sebuah konsep lingkungan perumahan penduduk yang secara bersamasama mengusahakan pekarangannya secara intensif untuk dimanfaatkan menjadi sumber pangan secara berkelanjutan dengan mempertimbangkan aspek potensi wilayah dan kebutuhan gizi warga setempat (Kementerian Pertanian, 2015). Purwantini et al. (2012) mengemukakan bahwa salah satu justifikasi penting dari Program KRPL adalah bahwa ketahanan pangan nasional harus dimulai dari ketahanan pangan di tingkat keluarga. Petunjuk Teknis P2KP Tahun 2015 menyebutkan tujuan khusus dari program ini adalah untuk meningkatkan partisipasi kelompok perempuan dalam penyediaan sumber pangan dan gizi keluarga melalui optimalisasi pemanfaatan pekarangan sebagai penghasil sumber karbohidrat, protein, vitamin dan mineral.

Kabupaten Bogor merupakan salah satu kabupaten yang melaksanakan program KRPL. Implementasi KRPL tentunya tidak dapat dilepaskan dari kondisi sosial masyarakat setempat, karena itu Pemerintah Kabupaten Bogor melibatkan kelembagaan yang sudah terbentuk di masyarakat yaitu Kelompok Wanita Tani (KWT) sebagai pengelola KRPL. Pelaksanaan KRPL meliputi 3 tahapan, yaitu tahap penumbuhan (tahun pertama), pengembangan (tahun kedua), dan mandiri (tahun ketiga). Pengalaman pembangunan di masa lalu membuat orang hanya berpikir pentingnya modal fisik dan keuangan, serta melupakan modal sosial yang dimiliki masyarakat (Ibrahim 2002). Ancok (2003) menyebutkan bahwa peranan modal sosial tidak kalah pentingnya dengan infrastruktur ekonomi lainnya.

KRPL memerlukan kerjasama dan gotong royong untuk mengelola sebuah kawasan agar lestari dan mencapai tujuan yang diharapkan bersama yaitu ketahanan pangan rumah tangga. Modal finansial berupa uang yang disalurkan kepada anggota kelompok, modal alam, modal fisik, dan modal manusia membutuhkan perekat untuk terjadinya tindakan kolektif yaitu modal sosial. Menurut Putnam (1993), modal sosial mengacu pada fitur organisasi sosial, seperti jaringan, norma, dan kepercayaan yang memfasilitasi koordinasi dan kerjasama untuk saling menguntungkan. Nilai-nilai sosial yang terpelihara dengan baik seperti kepercayaan, jejaring sosial, norma-norma merupakan kekuatan sosial. Nilai sosial ini diharapkan mampu menarik anggota masyarakat lainnya untuk turut menjadi bagian dari kelompok KRPL sehingga mampu tercipta suatu kawasan lestari yang semakin luas, sebagaimana yang tersebut pada Juknis P2KP bahwa diharapkan semakin bertambahnya Rumah Pangan Lestari (RPL).

Penelitian terdahulu bertemakan kinerja KRPL dilakukan oleh Widayanti (2015) dan Purwantini et al. (2012) menunjukkan bahwa KRPL memberikan dampak positif dan berhasil menghemat pengeluaran untuk konsumsi pangan. Penelitian yang dilakukan Fitrianingrum et al. (2016) menunjukkan bahwa program KRPL 
berjalan baik saat awal program dilaksanakan dan menjelang perlombaan semata. Penelitian yang dilakukan Suraningsih (2017) menyebutkan bahwa kegiatan pemanfaatan lahan pekarangan belum maksimal mendukung ketahanan pangan di tingkat keluarga. Bulu (2013) menyebutkan bahwa kelembagaan pada tingkat mikro merupakan basis berkembangnya modal sosial dari bawah, sehingga perlu diperkuat karena berpotensi menjadi penggerak pembangunan sosial. Alfiasari et al (2009) dalam penelitiannya mengemukakan bahwa modal sosial dapat dikembangkan dan dioptimalkan dalam bentuk kelembagaan-kelembagaan sosial di tingkat komunitas yang dapat menguatkan ketahanan pangan pada rumah tangga miskin, dengan mendasarkan pada bounded solidarity yang telah ada antar rumah tangga. Penyuluh sebagai petugas pendamping, perlu terus dimotivasi dan mendampingi perempuan serta KWT untuk dapat terus melakukan usahatani di lapangan (Manoppo et al.) Berdasarkan uraian latar belakang, maka penelitian ini bertujuan untuk: (1) mendeskripsikan kinerja dan hasil pemanfaatan lahan pekarangan melalui KRPL di Kabupaten Bogor; dan (2) merumuskan strategi penguatan modal sosial perempuan tani pada pemanfaatan lahan pekarangan terbatas di Kabupaten Bogor.

\section{Metode Penelitian}

Kajian diarahkan untuk mengukur dua aspek penting. Pertama, kinerja program KRPL di tiga desa studi. Kedua, menggali dan mengukur modal sosial, peran pendamping, dan pengelolaan administrasi di kelompok KRPL. Seluruh kajian dilaksanakan pada bulan Mei hingga Juli 2018. Kinerja KRPL diukur dengan metode survei di tiga desa studi di Kabupaten Bogor; yaitu Desa Cipayung Kecamatan Mega Mendung, Desa Benteng Kecamatan Ciampea, dan Desa Lumpang Kecamatan Parung Panjang. Ketiga desa yang dipilih merupakan desa yang menerima manfaat KRPL sejak tahun 2015. Kinerja KRPL diukur dari aspek pengelolaan kawasan (RPL, kebun bibit, dan demplot). Responden penelitian adalah 36 orang anggota kelompok pengelola KRPL yang meliputi 12 orang anggota di Desa Cipayung, 12 orang di Desa Benteng, dan 12 orang di Desa Lumpang. Data primer digali melalui wawancara dengan menggunakan daftar pertanyaan terstruktur (structured questionair).

Adapun untuk aspek modal sosial kelompok KRPL, peran pendamping, dan pengelolaan administrasi; pengumpulan data hanya dilakukan di Desa Cipayung. Untuk mengukur aspek-aspek ini diterapkan tiga metode. Pertama, metode penyusunan Profil Sosial Komunitas Desa Cipayung, pada bulan Oktober tahun 2016. Kedua, metode evaluasi kebijakan, yang dalam hal ini adalah Evaluasi Kebijakan Program Optimalisasi Pemanfaatan Lahan Pekarangan melalui Kawasan Rumah Pangan Lestari (KRPL) di Desa Cipayung pada tanggal 8 April sampai dengan $20 \mathrm{Mei}$ 2017. Ketiga, terakhir, digunakan metode kualitatif untuk pengumpulan data. Data dan informasi diperoleh dari enam informan yang ditetapkan melalui teknik purposive (dipilih secara sengaja). Informan yang terpilih adalah Dinas Ketahanan Pangan Pemerintah Kabupaten Bogor, Pendamping KRPL Tingkat Desa, Ketua Kelompok KRPL, anggota kelompok KRPL, dan perempuan tani bukan anggota kelompok KRPL. Data untuk aspek ini digali melalui wawancara mendalam, pengamatan berpartisipasi, dan catatan harian lapang. Data sekunder diperoleh dari dokumendokumen tertulis yang relevan dengan kajian.

Analisis data dibedakan berdasarkan dua pendekatan yang digunakan. Pengolahan data kuantitatif dilakukan dengan mengelompokkan data, kemudian disajikan dalam bentuk tabel frekuensi, grafik, dan diagram. Hasil data kuantitatif yang telah diolah kemudian diinterpretasikan secara 
deskriptif. Data kualitatif dianalisis melalui tiga tahapan, yaitu reduksi data, penyajian data, dan penarikan kesimpulan/ verifikasi. Metode perancangan strategi yang digunakan pada kajian ini adalah analisis SWOT (Strengths, Weaknesses, Opportunities, Threats) melalui proses FGD. David (2002) menyebutkan bahwa analisis SWOT merupakan alat pencocokan yang penting untuk membantu mengembangkan empat tipe strategi yang meliputi strategi S-O, W-O, S-T, dan W-T.

\section{Hasil dan Pembahasan}

\section{Karakteristik Responden}

Sebagian besar responden tidak memiliki lahan usaha tani yaitu sebesar 72,22\%.
Rata-rata luas lahan pekarangan adalah 26,63 $\mathrm{m}^{2}$. Berdasarkan Panduan KRPL Tahun Anggaran 2016 yang dikeluarkan oleh Pemerintah Kabupaten Bogor, angka tersebut tergolong pekarangan sempit. Rata-rata luas lahan yang digunakan untuk pengembangan RPL adalah $8,59 \mathrm{~m}^{2}$. Usia responden didominasi pada kelompok usia produktif, dimana kelompok usia tertinggi berada pada rentang usia 39-46 tahun yang mencapai $36,11 \%$. Sebanyak $88,89 \%$ responden adalah ibu rumah tangga dengan sumber penghasilan utama keluarga didominasi dari nonpertanian yaitu mencapai $86,11 \%$. Tingkat pendidikan responden terbanyak adalah lulusan $\mathrm{SD} /$ sederajat sebesar $\quad 66,66 \%$.

Tabel 1. Karakteristik Responden

\begin{tabular}{|c|c|c|c|c|}
\hline No & Karakteristik Responden & Jumlah & Satuan & Persentase \\
\hline \multirow[t]{5}{*}{1} & Penguasaan lahan usahatani & & & \\
\hline & a) $0 \mathrm{~m}^{2}$ & 26 & orang & $72,22 \%$ \\
\hline & b) $1-1.000 \mathrm{~m}^{2}$ & 6 & orang & $16,67 \%$ \\
\hline & c) $1.001-3.000 \mathrm{~m}^{2}$ & 3 & orang & $8,33 \%$ \\
\hline & d) $>3.000 \mathrm{~m}^{2}$ & 1 & orang & $2,78 \%$ \\
\hline \multirow[t]{4}{*}{2} & Rata-rata luas lahan pekarangan & 26,63 & $\mathrm{~m}^{2}$ & - \\
\hline & a) Desa Cipayung & 16,14 & $\mathrm{~m}^{2}$ & \\
\hline & b) Desa Benteng & 17,93 & $\mathrm{~m}^{2}$ & \\
\hline & c) Desa Lumpang & 45,83 & $\mathrm{~m}^{2}$ & \\
\hline \multirow[t]{4}{*}{3} & Rata-rata luas lahan untuk RPL & 8,59 & $\mathrm{~m}^{2}$ & - \\
\hline & a) Desa Cipayung & 5,14 & $\mathrm{~m}^{2}$ & \\
\hline & b) Desa Benteng & 5,29 & $\mathrm{~m}^{2}$ & \\
\hline & c) Desa Lumpang & 15,33 & $\mathrm{~m}^{2}$ & \\
\hline \multirow[t]{7}{*}{4} & Kelompok Usia Responden & & & \\
\hline & a) 23-30 tahun & 2 & orang & $5,56 \%$ \\
\hline & b) 31-38 tahun & 8 & orang & $22,22 \%$ \\
\hline & 39-46 tahun & 13 & orang & $36,11 \%$ \\
\hline & d) 47-54 tahun & 7 & orang & $19,44 \%$ \\
\hline & e) 55-62 tahun & 4 & orang & $11,11 \%$ \\
\hline & f) $63-70$ tahun & 2 & orang & $5,56 \%$ \\
\hline \multirow[t]{4}{*}{5} & Pekerjaan & & & \\
\hline & a) Ibu Rumah Tangga & 32 & orang & $88,89 \%$ \\
\hline & Petani & 2 & orang & $5,56 \%$ \\
\hline & Pedagang & 2 & orang & $5,56 \%$ \\
\hline \multirow[t]{3}{*}{6} & Sumber Penghasilan Utama & & & \\
\hline & a) Pertanian & 5 & keluarga & $13,89 \%$ \\
\hline & b) Nonpertanian & 31 & keluarga & $86,11 \%$ \\
\hline \multirow[t]{4}{*}{7} & Tingkat Pendidikan & & & \\
\hline & a) $\mathrm{SD} /$ sederajat & 24 & orang & $66,66 \%$ \\
\hline & $\mathrm{SMP} /$ sederajat & 6 & orang & $16,67 \%$ \\
\hline & c) $\mathrm{SMA} /$ sederajat & 6 & orang & $16,67 \%$ \\
\hline 8 & Rata-rata Jumlah Anggota Keluarga & 5 & orang & - \\
\hline
\end{tabular}

Sumber : Data Primer Diolah, 2018 


\section{Kinerja Program KRPL}

Ketiga kelompok di 3 desa studi merupakan penerima manfaat KRPL yang dimulai sejak tahun 2015. Ketiga kelompok tersebut adalah KWT Edellweis di Desa Cipayung, KWT Benteng Harapan di Desa Benteng, dan KWT Sekar Arum di Desa Lumpang. Kelompok tersebut menerima bantuan KRPL secara bertahap. Tahap pertama yaitu tahap penumbuhan, bantuan yang diterima adalah sebesar Rp.15 juta pada tahun 2015. Tahap kedua yaitu tahap pengembangan, bantuan disalurkan sebesar Rp.10 juta pada tahun 2016. Setelah melewati kedua tahap tersebut, kelompok KRPL diharapkan berada pada tahap mandiri. Permentan No. 18/Permentan/HK.140/4/ 2015 tentang Pedoman Gerakan Percepatan Penganekaragaman Konsumsi Pangan Tahun 2015, menyebutkan kegiatan yang dilakukan pada ketiga tahap tersebut adalah sebagai berikut.

Tahap Penumbuhan (Tahun Pertama). Pada tahap penumbuhan ini jumlah anggota kelompok minimal 15 rumah tangga. Pada tahap ini kelompok akan mendapatkan bantuan dan pendampingan oleh pendamping desa dengan kegiatan:

1. Sosialisasi optimalisasi pemanfaatan pekarangan oleh pendamping;

2. Pembuatan demplot pekarangan sebagai Laboratorium Lapangan (LL) sekaligus berperan sebagai pekarangan percontohan;

3. Pembuatan kebun bibit kelompok;

4. Pengembangan pekarangan anggota sebagai sumber pangan dan gizi keluarga;

5. Penyuluhan tentang pangan yang B2SA untuk hidup sehat, aktif, dan produktif.

Tahap Pengembangan (Tahun Kedua). Pada tahap ini jumlah anggota kelompok diharapkan sudah bertambah menjadi minimal 25 rumah tangga serta kegiatan pengolahan hasil KRPL menjadi penekanan untuk mengembangkan nilai ekonomis KRPL sehingga semakin memotivasi kelompok untuk melaksanakan kegiatan secara berkelanjutan. Pada tahap ini kelompok akan mendapat bantuan dan pendampingan oleh pendamping desa dengan kegiatan:

1. Pengembangan demplot kelompok;

2. Pengembangan kebun bibit kelompok;

3. Pengembangan pekarangan anggota sebagai sumber pangan dan gizi keluarga;

4. Demonstrasi penyediaan pangan dan penyiapan menu makanan yang beragam, bergizi seimbang, dan aman; dan

5. Pengolahan hasil KRPL.

Tahap Mandiri (Tahun Ketiga). Pada tahap ini kelompok masih mendapatkan bantuan dan pendampingan desa P2KP. Kegiatan diharapkan sudah eksis dan berlanjut dengan harapan kebun bibit sudah eksis dan terkelola dengan baik, demplot sudah berkembang, serta pekarangan anggota sudah berkembang secara berkelanjutan. Selain itu, diharapkan pada tahap ini jumlah anggota kelompok telah bertambah menjadi lebih dari 35 rumah tangga. Setiap pekarangan rumah anggota kelompok diharapkan dilengkapi dengan sarana pembuatan pupuk kompos dari sisasisa tanaman dan kotoran ternak dan sisa-sisa limbah dapur untuk digunakan sendiri. Ukuran pencapaian kinerja dalam kajian ini dapat dilihat pada Tabel 2, sedangkan hasil kinerja dapat dilihat pada Tabel 3. .

\section{KBD}

Dari ketiga desa, diketahui bahwa Desa Benteng sudah tidak memiliki kebun bibit. Penyebabnya adalah alih fungsi lahan yang digunakan sebagai kebun bibit menjadi kavling perumahan. Lahan tersebut memang dimiliki oleh perorangan diluar kelompok. Kedua desa lainnya, yaitu Desa Cipayung dan Desa Lumpang masih memiliki lahan dan bangunan kebun bibit namun sudah tidak berfungsi untuk memproduksi dan menyalurkan bibit bagi anggota, demplot, dan masyarakat. Kebun bibit cenderung terbengkalai pada kedua desa ini. Kondisi 
Tabel 2. Pengukuran Kinerja KRPL

\begin{tabular}{|c|c|c|c|}
\hline No & Indikator & Unit & Target \\
\hline \multicolumn{4}{|c|}{ Kebun Bibit } \\
\hline 1 & Keberadaan & - & Ada \\
\hline 2 & $\begin{array}{l}\text { Produksi dan distribusi } \\
\text { bibit }\end{array}$ & - & Masih \\
\hline \multicolumn{4}{|c|}{ Demplot } \\
\hline 3 & Keberadaan & - & Ada \\
\hline 4 & Masih Dikelola & - & Masih \\
\hline \multicolumn{4}{|c|}{ Rumah Pangan Lestari } \\
\hline 5 & $\begin{array}{l}\text { Pengembangan berbagai } \\
\text { komoditas }\end{array}$ & orang & 12 \\
\hline 6 & $\begin{array}{l}\text { Hasil pekarangan dapat } \\
\text { dipetik dalam sebulan }\end{array}$ & kali & 30 \\
\hline 7 & Jumlah RPL saat ini & rumah tangga & $>35$ \\
\hline
\end{tabular}

Tabel 3. Hasil Kinerja KRPL

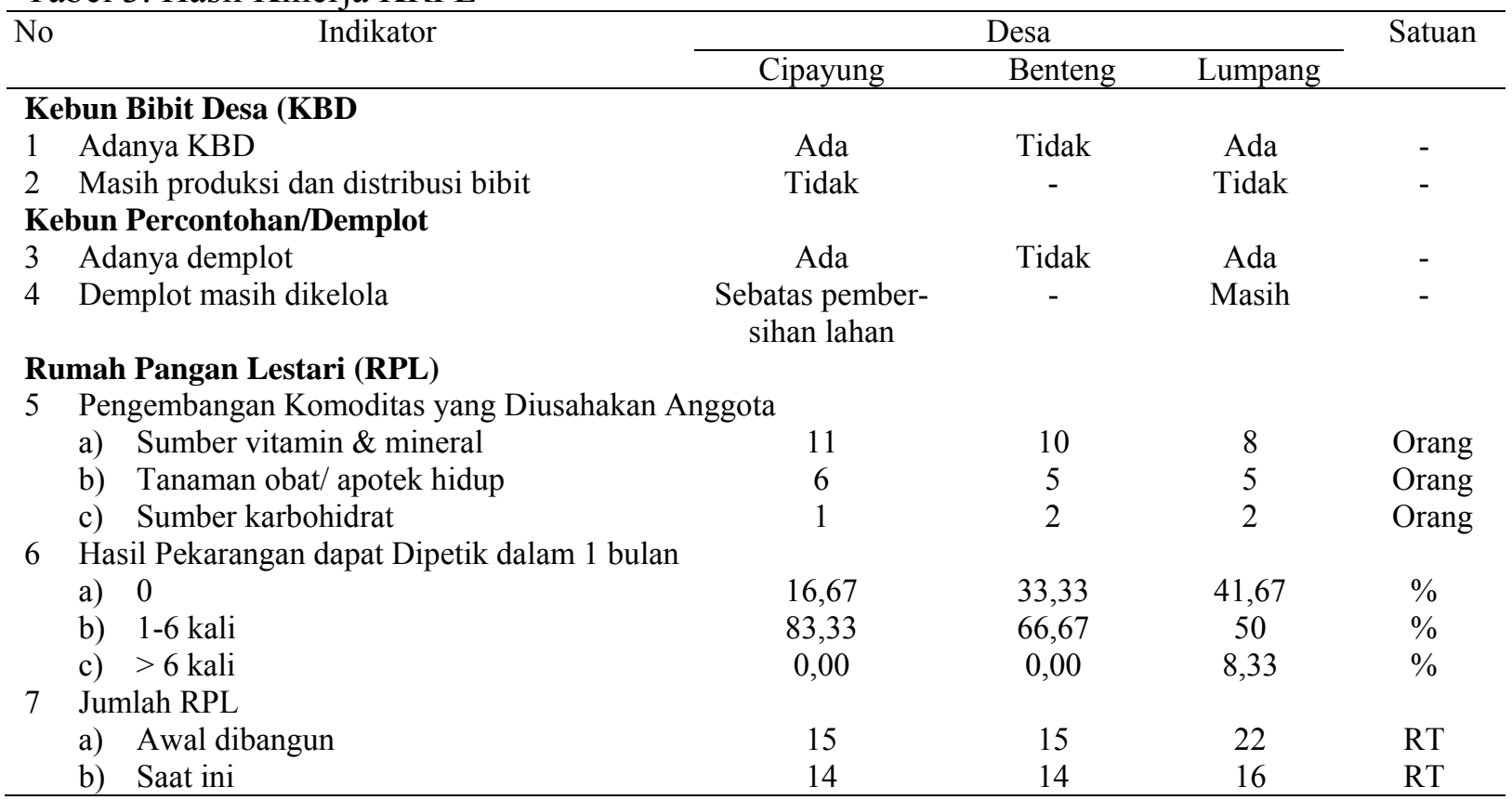

Sumber : Data Primer Diolah, 2018

kebun bibit saat ini pada ketiga desa studi menunjukkan kinerja yang masih jauh dari target yang diharapkan yaitu kebun bibit masih eksis dan dikelola dengan baik.

\section{Kebun Percontohan/Demplot}

Tabel 3 menunjukkan bahwa demplot di Desa Benteng sudah tidak ada karena berada pada satu lokasi dengan kebun bibit. Demplot di Desa Cipayung sudah tidak memproduksi dan menyalurkan bibit kepada anggota lagi, namun kegiatan pembersihan lahan masih dilakukan. Hal ini tetap dilakukan guna menjaga hubungan baik dengan pemilik lahan. Meskipun tidak rutin, secara bergantian anggota kelompok membersihkan lahan demplot dan kebun bibit yang berada pada satu kawasan. Kondisi yang sedikit berbeda terjadi di Desa Lumpang. Demplot di desa ini masih dikelola. Pengelolaan tidak dilakukan oleh kelompok melainkan perorangan oleh ketua kelompok. Demplot belum berfungsi sebagai laboratorium lapangan bagi anggota lainnya. Anggota kelompok belum menyadari manfaat dari program ini. Kinerja demplot pada Desa Lumpang lebih unggul dibandingkan kedua desa lainnya meskipun belum sesuai dengan yang diharapkan pada Juknis KRPL. 


\section{RPL}

1. Jenis Komoditas

Tabel 3 menunjukkan bahwa sumber vitamin \& mineral (sayuran dan buahbuahan) adalah komoditas yang paling banyak diusahakan anggota. Tanaman obat (kencur, jahe, brotowali, dll) berada di urutan kedua. Sumber karbohidrat (singkong, talas, jagung, dll), adalah komoditas yang paling sedikit ketersediannya di pekarangan anggota. Sementara itu, sumber protein (ternak ayam, bebek, kambing, dan ikan) tidak diukur dalam kajian ini karena selain rumah dengan pekarangan sempit, juga tidak sedikit rumah tanpa halaman. Sesuai Panduan KRPL Kabupaten Bogor, sumber protein hewani tidak masuk dalam arahan untuk rumah tanpa pekarangan.

Untuk mempertahankan pekarangan, anggota secara mandiri mendapatkan bibit dari sisa limbah dapur atau mengeluarkan dana pribadi untuk mengelola RPL. Hal ini dikarenakan kebun bibit sudah tidak dikelola secara berkelanjutan sehingga tidak ada bibit yang dapat didistribusikan kepada anggota. Ketiga desa memiliki kinerja yang masih di bawah target dalam mengembangkan berbagai komoditas terkait sumber pangan di pekarangan. Dari ketiga desa tersebut, tampak Desa Cipayung memiliki jumlah anggota yang lebih tinggi dalam mengusahakan beragam sumber pangan.

\section{Hasil Pekarangan yang Dapat Dipetik}

Meskipun tanpa dukungan dari kebun bibit, para perempuan tani cenderung masih memiliki tanaman di pekarangan. Dilihat dari jumlah hasil yang dapat dipetik dalam satu bulan, maka diketahui bahwa tanaman yang ada masih dalam jumlah yang sedikit dan belum mampu menjadi sumber pangan untuk memenuhi kebutuhan dapur sehari-hari. Pada umumnya, hasil pekarangan ini dimanfaatkan untuk dikonsumsi sendiri. Mayoritas anggota mampu memetik hasil pekarangan 1-6 kali dalam 1 bulan.
Kinerja ketiga desa dalam panen masih jauh dari harapan. Namun dapat diketahui bahwa Desa Cipayung lebih unggul dibanding kedua desa lainnya.

2. Jumlah RPL

Juknis P2KP menyebutkan bahwa pada tahun ketiga perogram dilaksanakan, diharapkan jumlah anggota telah bertambah minimal 35 rumah tangga. Kenyataan di lapangan, rumah tangga yang berpartisipasi dalam program ini semakin berkurang. Penyebabnya antara lain karena adanya anggota yang pindah menetap ke tempat lain dan kesibukan anggota dengan pekerjaan sehari-harinya. Jumlah RPL masih jauh dari target yang diharapkan.

\section{Analisis Kinerja KRPL}

Hasil kinerja ketiga desa studi masih jauh dari harapan yaitu kelompok dapat mandiri mengelola KRPL dan menjadikan kawasan semakin meluas. Kasus yang terjadi di Desa Lumpang, demplot masih dikelola dengan baik, tetapi kinerja RPL di pekarangan anggota cenderung rendah. Hal ini menunjukkan bahwa kesadaran anggota akan manfaat KRPL masih kurang. Manfaat KRPL perlu disampaikan terus-menerus mengingat kapasitas SDM cenderung rendah.

Kasus yang terjadi di Desa Cipayung, kinerja kebun bibit dan demplot rendah karena sudah tidak dikelola. Namun RPL masih dikelola oleh individu di masing-masing pekarangan. Semangat untuk bekerja secara berkelompok perlu ditingkatkan. Kondisi pekarangan cenderung lebih unggul dibanding kedua desa lainnya meskipun masih jauh dari target yang diharapkan. Ada upaya anggota untuk mempertahankan RPL di pekarangan. Anggota secara mandiri memanfaatkan limbah dapur dan bersedia mengeluarkan dana pribadi untuk mengelola KRPL seperti memperbaiki rak vertikultur ataupun membeli pupuk. Pendampingan yang dilakukan secara terjadwal diharapkan dapat membangun semangat anggota untuk bekerja 
secara berkelompok seperti saat tahun pertama program berjalan.

Kondisi Desa Benteng juga tidak jauh berbeda dari Desa Cipayung. RPL masih dikelola secara mandiri oleh anggota meskipun tanpa dukungan dari kebun bibit. Lahan kebun bibit yang diharapkan dapat digunakan minimal 3 tahun ternyata hanya dapat digunakan selama 2 tahun kegiatan berjalan. Untuk menghindari terjadinya hal serupa di masa mendatang, maka perjanjian penggunaan lahan untuk kebun bibit tanpa sewa ini perlu pendekatan khusus kepada pemilik lahan apabila dimiliki perorangan dan dicari alternatif solusinya apabila lahan sudah tidak dapat digunakan lagi. Penelitianpenelitian terdahulu yang bertemakan kinerja KRPL menunjukkan bahwa program KRPL ini memberikan dampak positif dari aspek sosial, ekonomi, dan ekologi. Program KRPL dapat menghemat pengeluaran kebutuhan pangan rumah tangga dari aspek ekonomi. Melihat kondisi KRPL di ketiga desa studi yang masih jauh dari target yang diharapkan pemerintah, maka dapat diketahui bahwa KRPL belum mampu dikelola oleh anggota secara berkelanjutan. Program KRPL cenderung memiliki tren kinerja yang menurun. Ketika tidak ada lagi bantuan dana kepada kelompok, anggota belum mampu mengelola secara mandiri aset yang telah dimiliki. KRPL masih dilihat sebagai proyek semata. Kesadaran kritis anggota dan masyarakat akan manfaat dari KRPL ini belum muncul.

\section{Analisis Modal Sosial Perempuan Tani}

\section{Gambaran Modal Sosial pada 3 Kelompok KRPL}

Modal sosial dilihat dari 3 aspek yaitu jaringan, kepercayaan, dan norma/nilai-nilai. Berikut ini adalah gambaran modal sosial di 3 kelompok KRPL.

Ketiga kelompok di ketiga desa studi memiliki kondisi sosial ekonomi yang tidak jauh berbeda. Karena itu, studi kasus dilakukan pada salah satu komunitas terpilih yaitu Kampung Cipayung Desa Cipayung untuk menggali modal sosial perempuan tani. Ife \& Tesoriero (2008) mengatakan bahwa modal sosial dapat dilihat sebagai perekat yang menyatukan masyarakat. Modal sosial yang akan dikaji dalam penelitian ini meliputi 3 komponen utama yang dikonseptualisasikan oleh Putnam yaitu norma/nilai-nilai sosial, kepercayaan, dan jaringan.

\section{Norma dan Nilai-nilai Sosial}

Kebiasaan menanam di pekarangan sebetulnya sudah ada sejak lama di masyarakat. Begitu pula di Kampung Cipayung, sebelum masuknya program KRPL sudah terdapat warga yang memanfaatkan lahan sempitnya untuk menanam meskipun jumlahnya tidak banyak. Rumah tanpa tanaman di halaman cukup banyak dijumpai di kampung ini. Keterbatasan lahan menjadi alasan para ibu rumah tangga tidak dapat melakukan pemanfaataan lahan pekarangan.

Sebelum masuknya program KRPL, tanaman yang dibudidayakan di pekarangan rumah umumnya berfungsi sebagai estetika. Sudah menjadi kebiasaan warga untuk saling berbagi kepada tetangga apabila ada yang tertarik dengan tanaman yang ada di pekarangan rumahnya. Apabila ada warga yang memerlukan tanaman obat, mereka dapat memintanya kepada warga yang memilikinya. Semua dilakukan sebagai tindakan tolong-menolong antara tetangga, tidak ada nilai komersil terhadap tanaman yang diberikan. Tanaman pekarangan belum dianggap sesuatu yang potensial yang dapat memenuhi kebutuhan pangan dan gizi keluarga dan mampu menjadi usaha ekonomi produktif keluarga. Sejak masuknya program KRPL, pola pikir perempuan tani anggota kelompok terhadap pekarangan mulai bergeser. Anggota kelompok mulai menyadari bahwa pekarangan tidak hanya berfungsi untuk estetika, tetapi dapat bermanfaat untuk mengurangi pengeluaran 
Tabel 4. Gambaran Modal Sosial di 3 Kelompok KRPL

\begin{tabular}{|c|c|c|c|c|c|c|c|}
\hline \multirow[t]{2}{*}{ No } & \multirow[t]{2}{*}{ Indikator } & \multicolumn{2}{|c|}{ Desa Cipayung } & \multicolumn{2}{|c|}{ Desa Benteng } & \multicolumn{2}{|c|}{ Desa Lumpang } \\
\hline & & $\mathrm{Jml}$ & $\%$ & Jml & $\%$ & $\mathrm{Jml}$ & $\%$ \\
\hline \multicolumn{8}{|c|}{ Jaringan } \\
\hline \multicolumn{8}{|c|}{1 Jumlah Organisasi yang Diikuti } \\
\hline $\mathrm{a}$ & a) 1 & 2 & 16,67 & 3 & 25,00 & 6 & 50 \\
\hline $\mathrm{b}$ & b) 2 & 6 & 50,00 & 8 & 66,67 & 6 & 50 \\
\hline $\mathrm{c}$ & c) 3 & 4 & 33,33 & 1 & 8,33 & 0 & 0 \\
\hline \multirow{2}{*}{\multicolumn{8}{|c|}{$\begin{array}{l}2 \text { Hasil KBD Dimanfaatkan Masyarakat Lain } \\
\text { Kepercayaan }\end{array}$}} \\
\hline & & & & & & & \\
\hline \multicolumn{8}{|c|}{3 Menggantikan merawat tanaman apabila perempuan tani sedang tidak di rumah } \\
\hline $\mathrm{a}$ & a) Suami & 9 & 75,00 & 3 & 25,00 & 6 & 50,00 \\
\hline & b) Anak & 2 & 16,67 & 6 & 50,00 & 4 & 33,33 \\
\hline $\mathrm{c}$ & c) Tidak ada & 1 & 8,33 & 3 & 25,00 & 2 & 16,67 \\
\hline \multicolumn{8}{|c|}{4 Mengikuti kegiatan penyuluhan dalam 1 Tahun } \\
\hline & a) $0-5$ kali & 2 & 16,67 & 7 & 58,33 & 5 & 41,67 \\
\hline & b) $\geq 6$ kali & 10 & 83,33 & 5 & 41,67 & 7 & 58,33 \\
\hline \multicolumn{8}{|c|}{5 Mengikuti pelatihan KRPL } \\
\hline & a) Pernah & 4 & 33,33 & 1 & 8,33 & 3 & 25,00 \\
\hline & b) Tidak & 8 & 66,67 & 11 & 91,67 & 9 & 75,00 \\
\hline \multicolumn{8}{|c|}{ Nilai-nilai/Norma } \\
\hline \multicolumn{8}{|c|}{7 Menghadiri rapat kelompok } \\
\hline $\mathrm{a}$ & a) Selalu & 10 & 83,33 & 8 & 66,68 & 10 & 83,33 \\
\hline & b) Tidak & 2 & 16,67 & 4 & 22,22 & 2 & 16,67 \\
\hline \multicolumn{8}{|c|}{8 Merawat Tanaman Setiap Hari } \\
\hline & a) Iya & 10 & 83,33 & 10 & 83,33 & 7 & 58,33 \\
\hline $\mathrm{b}$ & b) Tidak & 2 & 16,67 & 2 & 16,67 & 5 & 41,67 \\
\hline \multicolumn{8}{|c|}{9 Lamanya Merawat Tanaman dalam Sehari } \\
\hline & a) $<30$ & 11 & 91,67 & 12 & 100 & 10 & 83,33 \\
\hline & $30-60$ & 1 & 8,33 & 0 & 0 & 0 & 0,00 \\
\hline & $>60$ & 0 & 0 & 0 & 0 & 2 & 16,67 \\
\hline
\end{tabular}

Sumber : Data Primer Diolah, 2018

rumah tangga dan mampu memenuhi kebutuhan pangan dan gizi keluarga. Setiap anggota memiliki tanaman di halaman/pekarangan rumahnya yang meliputi tanaman sayuran, buah, dan obat, tidak terbatas pada tanaman hias saja. Teknologi vertikultur digunakan untuk menyiasati sempitnya lahan pekarangan dengan menggunakan paralon, botol bekas, dan polybag.

Program KRPL mengharapkan hasil panen dari pekarangan dapat dimanfaatkan untuk konsumsi sendiri, dan apabila berlebih dapat dijual untuk menambah pendapatan keluarga. Bagi anggota kelompok di Kampung Cipayung, berbagi tanaman pekarangan kepada warga lain yang meminta adalah kebiasaan yang sudah dilakukan jauh sebelum masuknya program KRPL. Ketika tanaman di pekarangan dapat dipanen, hasil yang berlebih dibagi-bagikan kepada tetangga sekitar, tidak ada anggota yang menjual hasil panen yang berlebih. Anggota kelompok merasa segan apabila harus menetapkan tarif karena yang berminat dengan hasil panen tersebut adalah tetangga dekat.

Untuk menjaga keberlanjutan KRPL, kelompok berusaha membuat kesepakatan bersama terkait pengelolaan kebun bibit dan kebun percontohan. Beberapa kesepakatan tersebut antara lain dengan membuat jadwal piket harian untuk membersihkan kebun bibit, ketentuan distribusi bibit, dan kesepakatan hasil penjualan.

\section{Jadwal Piket Harian.}

Jadwal piket dibuat secara tertulis dan diatur pembagiannya sehingga setiap orang mendapat bagian sekali dalam seminggu untuk membersihkan kebun bibit. Kegiatan 
yang dilakukan saat piket antara lain penyiraman dan penyiangan gulma. Tidak ada sanksi yang diberikan apabila seorang anggota tidak dapat melaksanakan piket sesuai jadwal. Kegiatan piket menjadi saling mengandalkan satu sama lain dan pada akhirnya tidak berlangsung secara berkelanjutan.

\section{Kesepakatan Distribusi Bibit.}

Distribusi bibit kepada anggota kelompok diberikan secara gratis, dengan syarat anggota harus mengembalikan bibit yang diambilnya. Anggota yang tidak mampu mengembalikan bibit, maka harus membayar denda sesuai nilai bibit yang diambil berkisar antara Rp. 1.000,00 - 2.000,00 per bibit atau seikhlasnya apabila ada yang ingin membayar lebih. Uang tersebut akan masuk ke dalam kas kelompok dan dipergunakan untuk membeli benih/bibit lagi demi keberlanjutan produksi bibit. Tidak ada sanksi kepada anggota yang tidak mampu mengembalikan bibit dan tidak juga membayar dendanya.

Tidak banyak warga masyarakat yang turut memanfaatkan bibit di kebun. Apabila ada yang meminta, maka oleh kelompok diberikan saja tanpa memberikan tarif. Kebun bibit belum sampai pada tahap komersil dengan menjual bibit yang diproduksi. Bibit juga belum dapat dimanfaatkan oleh masyarakat luas. Hanya sesekali saja ada warga lain yang meminta, selebihnya bibit dimanfaatkan oleh anggota kelompok saja. Kesepakatan mengenai distribusi bibit ini ternyata tidak berlangsung lama. Tidak seimbangnya antara benih yang keluar dengan benih yang diproduksi menyebabkan akhirnya tidak ada lagi bibit yang dapat dimanfaatkan di kebun bibit.

\section{Kesepakatan Hasil Penjualan.}

Anggota kelompok memiliki kesepakatan bersama dalam hal bagi hasil penjualan untuk memasukan dana tersebut ke dalam kas kelompok. Dana tersebut selanjutnya agar dimanfaatkan untuk keperluan kelompok.
Pada tahun pertama kegiatan KRPL berjalan, hasil kebun percontohan mampu dijual oleh anggota kepada warga sekitar dan pedagang mie ayam yang ada di lingkungan sekitar. Tidak semua hasil panen dijual dalam bentuk segar, ada pula yang diolah terlebih dahulu untuk meningkatkan nilai jual, seperti keripik singkong Sayanganya, hal ini juga tidak berlangsung lama. Seiring berjalannya waktu, kebun percontohan menjadi tidak eksis dan tidak ada hasil panen yang dapat diolah oleh kelompok untuk dijual. Sulitnya mengajak seluruh anggota untuk secara kontinu mengelola kebun percontohan menjadi salah satu alasan kebun percontohan berhenti dikelola. Selain itu, faktor cuaca juga menyebabkan anggota kelompok tidak pergi ke kebun. Akibat terlalu lama tidak ke kebun, akhirnya kesepakatan-kesepakatan yang sudah dibuat bersama untuk mengelola kebun percontohan secara kontinu menjadi terlupakan.

\section{Kepercayaan}

Bantuan sosial dengan total sebesar $\mathrm{Rp} 25$ juta bukanlah nilai yang kecil bagi perempuan tani di Kampung Cipayung. Bantuan pemerintah diberikan dalam bentuk uang yang ditransfer langsung ke rekening kelompok KRPL. Dana bantuan tersebut dialokasikan dalam bentuk pengadaan barang oleh kelompok yang meliputi: bahan dan alat untuk bangunan fisik KBD; bahan dan alat pengembangan demplot; bahan dan alat pengembangan pekarangan; dan alat pengolahan hasil yang sederhana.

Ketentuan yang dibuat pemerintah adalah bantuan tidak diterima dalam bentuk uang, melainkan dalam bentuk bahan dan alat yang diperlukan untuk pengembangan KRPL. Hal ini ternyata tidak seluruhnya mampu dipahami oleh seluruh anggota kelompok. Meskipun telah dilakukan sosialisasi, tetapi tidak seluruhnya mampu memahami ketentuan penggunaan bantuan KRPL. Kapasitas SDM yang rendah menjadi salah satu kendala bagi sebagian kecil perempuan 
tani untuk memahami aturan tersebut. Ada anggota yang menghendaki bantuan diberikan dalam bentuk uang tunai dan mempertanyakan penggunaan dana tersebut. Dari satu orang anggota tersebut ternyata memberikan pengaruh kepada anggota lainnya. Pendamping dan pengurus memberi penjelasan tentang ketentuan penggunaan dana KRPL kepada seluruh anggota.

\section{Jaringan}

Jaringan kelompok KRPL cenderung terkait dengan instansi-instansi pemerintah, terutama dengan lembaga pelaksana KRPL seperti UPT Pertanian Ciawi dan Dinas Ketahanan Pangan Kabupaten Bogor. Kelompok KRPL juga memiliki jaringan dengan kelompok tani lainnya yang berada pada satu desa tetapi masih lemah. KWT Edellweis ebagai pelaksana program KRPL di tingkat mikro merupakan bagian dari Gabungan Kelompok Tani (Gapoktan) yang dibentuk pada tahun 2012 di Desa Cipayung. Gapoktan ini merupakan kumpulan beberapa kelompoktani tetapi belum mampu berfungsi sebagai wadah kerjasama untuk meningkatkan skala ekonomi dan efisiensi usaha. Jaringan kelompok juga ditunjukkan dengan Badan Usaha Milik Negara (BUMN) yakni PT. PLN (Persero). PLN juga melakukan pendampingan terhadap para ibu rumah tangga di Desa Cipayung dan sekitarnya yang baru mulai dilakukan pada tahun 2018.

\section{Peran Pendamping}

Pelaksanaan program KRPL di Desa Cipayung mendapatkan pendampingan langsung dari pendamping tingkat desa yang merupakan penyuluh pertanian yang bertugas di desa tersebut. Sebagai penyuluh pertanian, pendamping sudah dikenal baik dengan kelompok. Kegiatan pemanfaatan lahan pekarangan di Desa Cipayung, pertama kali diperkenalkan oleh Pendamping sejak awal tahun 2015. Pendampingan dilakukan mulai dari sosialisasi, pengelolaan administrasi, pembuatan dan pengembangan kebun bibit, pembuatan dan pengembangan demplot, pembuatan dan pengembangan RPL di pekarangan anggota, pengolahan hasil, hingga demonstrasi penyediaan pangan yang B2SA (beragam, bergizi, seimbang, dan aman).

Kunjungan dilakukan secara rutin 2-3 kali dalam sebulan pada tahun 2015 yang merupakan tahap penumbuhan. Interaksi yang tinggi terjadi antara pendamping dengan kelompok pada tahap ini. Memasuki tahun 2017, pertemuan sudah semakin berkurang, kunjungan hanya satu kali dalam sebulan bahkan kurang dari itu. Mengacu pada Petunjuk Teknis P2KP dimana pada tahun ketiga kelompok sudah berada pada tahap mandiri dimana pada tahap ini kelompok masih mendapatkan bantuan dan pendampingan desa.

Penyebab berkurangnya frekuensi kunjungan pendamping adalah karena pendamping bertugas sebagai penyuluh yang memiliki wilayah binaan sebanyak 4 desa dimana dalam satu desa terdapat beberapa kelompoktani. Tugas dan tanggungjawab penyuluh sebagai pendamping KRPL, tidak hanya berfokus pada perempuan tani dan program pemanfaatan lahan pekarangan. Setiap tahun, prioritas kegiatan bisa berbeda sehingga jadwal kunjungan akan lebih sering dilakukan untuk kegiatan yang menjadi prioritas tersebut.

\section{Pengelolaan Administrasi}

Pengelolaan administrasi kelompok dalam program KRPL ini tidak dapat dilepaskan dari peran pendamping. Pendamping membantu mulai dari penyusunan RKKA hingga menyusun laporan pertanggungjawaban. Catatan administrasi yang dimiliki kelompok dalam pengelolaan KRPL ini antara lain buku daftar anggota kelompok, lampiran bukti transaksi, buku distribusi barang, buku pengelolaan kebun bibit, buku inventaris barang, buku realisasi kegiatan, dan buku kas umum. Pencatatan ini belum dilakukan secara tertib sehingga belum dapat menggambarkan seluruh 
kegiatan yang telah dilaksanakan. Pengelolaan administrasi dalam kelompok cenderung dilakukan pada tahun pertama kegiatan berjalan.

\section{Hasil Analisis SWOT (Faktor Internal \& Eksternal)}

Faktor Internal (Kekuatan) :

1. Adanya potensi pekarangan meskipun sempit.

2. Toleransi yang terjaga dengan baik diantara anggota kelompok. Apabila muncul suatu masalah di dalam kelompok, maka anggota tidak ingin memperbesar masalah karena tidak ingin merusak hubungan bertetangga.

3. Kegiatan sehari-hari para perempuan tani lebih banyak berada di rumah sehingga di sela-sela waktunya dapat dimanfaatkan untuk mengurus tanaman.

4. Anggota kelompok cenderung memiliki minat yang tinggi pada bidang pengolahan hasil pertanian.

5. Kondisi SDA yang mendukung.

6. Produk yang dihasilkan dari KRPL merupakan produk organik.

Faktor Internal (Kelemahan) :

1. Rendahnya jaringan kelompok.

2. Lemahnya kemampuan manajerial kelompok. Tanpa kehadiran pendamping, kelompok masih sulit untuk bekerja secara mandiri.

3. Belum terbangunnya kepercayaan yang dapat membangun kerjasama kelompok.

4. Kapasitas SDM yang rendah.

5. Catatan administrasi kegiatan pengelolaan KRPL belum tercatat dengan rapi.

6. Belum mampu memahami peran dan tanggungjawabnya masing-masing sehingga saling mengandalkan.

7. Kurangnya motivasi untuk bertani. Sebagian besar sumber penghasilan utama keluarga berasal dari nonpertanian.

8. Kesibukan perempuan tani anggota KRPL dengan tugas utama sebagai ibu rumah tangga yang mengurus keluarga.
Faktor Eksternal (Peluang) :

1. Terbukanya peluang untuk meningkatkan kapasitas SDM, baik dari instansi pemerintah maupun BUMN/D.

2. Adanya pendamping KRPL tingkat desa yang mendampingi pengelolaan KRPL sebagai tempat untuk berdiskusi dan membantu memecahkan masalah bersama-sama.

3. Perkembangan IPTEK yang memudahkan anggota kelompok mengakses informasi terkait pertanian, memudahkan sesama anggota saling berkomunikasi, dan memperkenalkan KRPL yang dikelola kepada masyarakat luas.

4. Adanya dukungan kebijakan terkait pemanfaatan lahan pekarangan. Kegiatan ini mendapat dukungan kebijakan yaitu Undang-Undang tentang Pangan No. 12 Tahun 2012 dan Perpres No. 22 Tahun 2009 tentang Kebijakan P2KP Berbasis Sumberdaya Lokal.

5. Produk organik menjadi gaya hidup baru dalam masyarakat untuk menjalankan pola hidup sehat.

Faktor Eksternal (Ancaman) :

1. Perkembangan zaman yang dapat mengikis rasa kebersamaan anggota dan tradisi gotong royong.

2. Serangan hama dan penyakit.

3. Kondisi cuaca yang tidak menentu.

4. Rendahnya partisipasi masyarakat terhadap kegiatan KRPL.

5. Jumlah penyuluh sebagai pendamping KRPL belum memadai.

6. Belum optimalnya peran pemerintah desa untuk pengembangan KRPL.

\section{Strategi Penguatan Modal Sosial Perempuan Tani}

1. Mengatur pola pendampingan rutin dan terjadwal. Pendampingan dilakukan dengan pola yang terjadwal secara intensif dan berkelanjutan. Pendekatan tidak hanya dilakukan kepada pengurus, tetapi juga kepada anggota kelompok lainnya. Pendampingan tidak dibatasi pada tahap 
pengembangan, tetapi masih perlu berlanjut pada tahun ketiga. Karena itu, pendampingan yang intensif pada tahap penumbuhan untuk tetap dipertahankan pada tahap pengembangan.

2. Meningkatkan kompetensi perempuan tani melalui pelatihan manajerial kelompok, teknis budidaya, kewirausahaan, pemasaran, dan pengolahan hasil pertanian. Bulu (2013) mengatakan bahwa dalam pelaksanaan pembangunan di daerah yang berbasis pengembangan ekonomi wilayah pedesaan, modal manusia (human capital) dan modal sosial (social capital) merupakan dua konsep yang berbeda, namun keduanya merupakan dua kutub yang saling melengkapi dalam pengembangan sumberdaya manusia (SDM). Peningkatan kapasitas perempuan tani, baik anggota maupun pengurus baik dalam bidang manajerial, administrasi kelompok, teknis budidaya, kewirausahaan, dan pengolahan hasil pertanian. studi banding juga perlu dilakukan untuk mempelajari keberhasilan kelompok lainnya.

3. Melibatkan peran tokoh masyarakat dan keluarga dalam pengelolaan KRPL. Tokoh masyarakat diajak berperan serta dalam pengelolaan KRPL. Selain tokoh masyarakat, anggota masyarakat lainnya terutama anggota keluarga diajak berpartisipasi agar turut merasa bahwa kegiatan KRPL adalah milik bersama bukan hanya milik anggota kelompok. Keluarga sebagai sistem sosial terkecil juga perlu ditanamkan kesadaran akan manfaat dari KRPL. Masyarakat juga turut diperkenalkan dengan manfaat kegiatan dan diajak mencoba untuk menerapkannya agar muncul ketertarikan.

4. Meningkatkan kompetensi dan peran pendamping. Peningkatan kompetensi pendamping dilakukan baik dalam teknis budidaya, kewirausahaan, dan komunikasi. Pendamping Tingkat Desa berperan tidak hanya sebagai mendampingi kelompok dalam mengelola
KRPL, tetapi juga berperan sebagai motivator dan advisor. Bulu (2013) menyebutkan bahwa motivasi merupakan energi bagi bekerjanya modal sosial dalam pemenuhan individu dan kelompok.

5. Meningkatkan interaksi di antara anggota kelompok dan antar kelompok KRPL. Interaksi antar anggota kelompok dapat didorong melalui kegiatan khas ibu rumah tangga seperti arisan dan pengajian rutin secara bergilir di rumah masing-masing perempuan tani dan masyarakat lainnya. Kegiatan tersebut juga dapat meningkatkan kepercayaan antar anggota. Selain itu, interaksi juga dapat ditingkatkan dengan mendorong tradisitradisi yang sudah mulai terkikis seperti gotong royong untuk dihidupkan kembali. Interaksi antar kelompok KRPL dapat ditingkatkan dengan mengikuti berbagai kegiatan perlombaan, pameran, dan bazaar yang diadakan oleh pemerintah daerah. Anggota didorong untuk memiliki kemitraan dengan kelompok KRPL lainnya. Hal ini juga turut memperluas jejaring sosial anggota.

\section{Simpulan}

Berdasarkan hasil kajian yang telah dilakukan, Hasil kajian tentang kinerja KRPL menunjukkan bahwa, pertama, kebun bibit dan demplot sudah tidak eksis setelah 3 tahun program diimplementasikan. Sementara itu, RPL masih dikelola secara mandiri oleh anggota. Untuk mengelola RPL, perempuan tani memanfaatkan limbah dapur ataupun mengeluarkan dana pribadi untuk pengembangan RPL.

Dari segi modal sosial, jaringan perempuan tani cenderung terbatas pada instansi pemerintah. Kepercayaan dalam mengelola tanaman cenderung kepada anggota keluarga. Nilai-nilai dalam pemanfaatan pekarangan yang awalanya hanya bernilai estetika telah bergeser dengan mengusahakan berbagai jenis komoditas sebagai sumber pangan dan gizi keluarga. Dari segi pendamping, pola pendampingan perlu ditingkatkan pada tahun 
ketiga karena pada tahap ini anggota teryata belum mampu mandiri mengelola KRPL. Dari segi pengelolaan administrasi, kompetensi perempuan tani perlu ditingkatkan dan perlu pendampingan yang intensif dalam hal administrasi.

Aksi yang direkomendasikan untuk menghindari kegagalan KRPL di masa mendatang sebagai strategi penguatan modal sosial adalah: 1) mengatur pola pendampingan rutin dan terjadwal; 2) meningkatkan kompetensi perempuan tani melalui pelatihan manajerial kelompok, teknis budidaya, kewirausahaan, pemasaran, dan pengolahan hasil pertanian; 3) melibatkan peran tokoh masyarakat dan keluarga dalam pengelolaan KRPL; 4) meningkatkan kompetensi dan peran pendamping; dan terakhir 5) meningkatkan interaksi di antara anggota kelompok dan antar kelompok KRPL.

\section{Daftar Pustaka}

Alfiasari, Martianto D, Dharmawan AH. 2009. Modal Sosial dan Ketahanan Pangan Rumah Tangga Miskin di kecamatan Tanah Sareal dan Kecamatan Bogor Timur, Kota Bogor. J. Sodality [Internet]. [diunduh 2018 Januari 10]; 3 (1):135-166 : Bogor (ID). Tersedia pada: http://journal.ipb.ac.id/index.php/ sodality/article/ view/5869/4534

Aminah, Sumardjo, Lubis, Susanto. 2015. Strategi Peningkatan Keberdayaan Petani Kecil Menuju Ketahanan Pangan. Sosiohumaniora. [Internet]. [Diunduh 2018 Juli 18]; 17(3):253-261. Tersedia pada:

http://jurnal.unpad.ac.id/sosiohumaniora/a rticle/view/8343/6617

Ancok D. 2003. Modal Sosial dan Kualitas Masyarakat. Psikologika [Internet]. [diunduh 2017 Desember 4]; 15(8):4-14: Yogyakarta (ID). Tersedia pada : http://www.jurnal.uii.ac.id/index.php/Psik ologika/article/view File/317/7342

[BKP5K] Badan Ketahanan Pangan dan Pelaksana Penyuluhan Pertanian,
Perikanan, dan Kehutanan. Panduan Kawasan Rumah Pangan Lestari (KRPL) Tahun Anggaran 2016. Bogor (ID): Pemerintah Kabupaten Bogor.

Bulu YG. 2013. Penguatan Modal Sosial Kelembagaan Tani dalam Mendukung Pengembangan Usaha Agribisnis Perdesaan. Di dalam: Ariani M, Suradisastra K, Saad NS, Hendayana R, Soeparno H, Pasandara E, editor. Diversifikasi Pangan dan Transformasi Pembangunan Pertanian. Jakarta (ID): IAARD Press. hlm 478-493.

David FR. 2002. Manajemen Strategi Konsep. Edisi ke-7. Jakarta (ID): PT. Prenhallindo.

Fitrianingrum, Rosdiana. 2016. Evaluasi Pelaksanaan Program Kawasan Rumah Pangan Lestari (KRPL). Publika. [Internet]. [diunduh pada 2017 April 29]; 4(7):1-7. Suranaya (ID). Tersedia pada: http://jurnalmahasiswa.unesa.ac.id/index.p $\mathrm{hp} /$ publika/article/view/15097

Ibrahim LD. 2002. Kehidupan Berorganisasi sebagai Modal Sosial Komunitas Jakarta. Jurnal Masyarakat. 11:62-88.

Ife J, Tesoriero F. 2008. Community Development: Alternatif Pengembangan Masyarakat di Era Globalisasi. Pustaka Pelajar: Yogyakarta.

[Kementan] Kementerian Pertanian, Badan Ketahanan Pangan. 2002. Peraturan Pemerintah Republik Indonesia Nomor 68 Tahun 2002 tentang Ketahanan Pangan. Jakarta (ID) : Kementerian Pertanian.

[Kementan] Kementerian Pertanian. 2012. Undang-Undang Nomor 18 Tahun 2012 tentang Pangan [Internet]. [diunduh 2017 Desember 8]. Tersedia pada: http://bkp.pertanian.go.id/tinymcpuk/gam bar/file/UU Nomor_18 Tahun_2012(1).p $\underline{\mathrm{df}}$

[Kementan] Kementerian Pertanian. 2015. Keputusan Menteri Pertanian Republik Indonesia Nomor 18/Permentan/HK.140/4/2015 tentang Pedoman Gerakan Percepatan Penganekaragaman Konsumsi Pangan 
Tahun 2015. Jakarta (ID): Kementerian Pertanian.

[Kementan] Kementerian Pertanian. 2016. Keputusan Menteri Pertanian Republik Indonesia Nomor 12/KPTS/KN.210/K/02/2016 tentang Petunjuk Teknis Gerakan Percepatan Penganekaragaman Konsumsi Pangan Tahun 2016. Jakarta (ID): Kementerian Pertanian.

Manoppo, Amanah, Asngari, Tjitropranoto. 2017. Persepsi Perempuan terhadap Pemanfaatan Pekarangan Mendukung Diversifikasi Pangan di Sulawesi Utara. Jurnal Penyuluhan. [Internet]. [diunduh 2018 Juli 18]; 13(1)40-50. Bogor (ID). Tersedia pada: http://journal.ipb.ac.id/index.php/jupe/arti cle/view/13560/11626

Purwantini TB, Saptana, Suharyono S. 2012. Program Kawasan Rumah Pangan Lestari (KRPL) di Kabupaten Pacitan : Analisis Dampak dan Antisipasi ke Depan. Analisis Kebijakan Pertanian. [Internet]. [diunduh 2017 Desember 2]; 10(3):239256. Bogor (ID). Tersedia pada : http://ejurnal.litbang.pertanian.go.id/index .php/akp/article/view/4090/3417
Putnam RD. 1993. The Prosperous Community: Social Capital and Public Life. The American Prospect Online (Spring) [Internet]. [diunduh 2017 Desember 8]. Tersedia pada: http://prospect.org/article/prosperouscommunity-social-capital-and-public-life Saptana, Sunarsih, Friyatno. 2013. Prospek Model-Kawasan Rumah Pangan Lestari (M-KRPL) dan Replikasi Pengembangan KRPL. Forum Penelitian Agro Ekonomi. [Internet]. [diunduh 2017 April 25]; 31(1):67-87. Bogor (ID). Tersedia pada: http://ejurnal.litbang.pertanian.go.id/index . php/fae/article/view/3846/3194

Suraningsih MS. 2017. Strategi Komunikasi Keberdayaan Wanita Tani melalui Pemanfaatan Pekarangan menuju Ketahanan Pangan Keluarga [disertasi]. Bogor (ID): Institut Pertanian Bogor.

Widayanti. 2015. Evaluasi Kinerja Model Kawasan Rumah Pangan Lestari pada Balai Besar Pengkajian dan Pengembangan Teknologi Pertanian Melalui Pendekatan Balance Scorecard [skripsi]. Bogor (ID): Institut Pertanian Bogor. 